\title{
Kajian Desain Gapura dengan Konsep Green Design sebagai Upaya Pembentuk Identitas suatu Lingkungan
}

\author{
Mahendra Wardhana ${ }^{1}$, Anggri Indraprasti ${ }^{2}$, Nadya Rizky Fitriana ${ }^{3}$ \\ ${ }^{1,2}$ Dosen Departemen Desain Interior, FTSP Institut Teknologi Sepuluh Nopember \\ mahendra@interior.its.ac.id, indraprasti@yahoo.com \\ ${ }^{3}$ Mahasiswa Departemen Desain Interior, FTSP Institut Teknologi Sepuluh Nopember
}

\begin{abstract}
ABSTRAK
Identitas lingkungan menjadi sangat penting untuk diwujudkan dan diperhatikan dikarenakan hal ini akan menjadi panduan bagi semua orang yang berada di dalamnya untuk mengetahui posisi serta keberadaannya pada lingkungan tersebut. Keberadaan yang dimaksud ini adalah kemudahan dalam menemukan posisinya dalam suatu lingkungan dalam kaitan dengan jarak dan arah terhadap suatu titik tujuannya. Dengan demikian, hal yang dijadikan perhatian atau faktor penting dalam analisa identitas lingkungan adalah view, posisi dan jarak suatu penanda di lingkungan tertentu.

Salah satu obyek kajian yang penting dalam memnentuk identitas lingkungan adalah gapura masuk di lingkungan rukun tetangga. Dalam kajian gapura ini tetap dimunculkan konsep green design dikarenakan banyak upaya di lingkungan suatu kota yang cenderung membentuk lingkungan hijau di lingkungannya. Konsep green design pada gapura selalu berkaitan dengan tanaman dan taman yang berada di sekitar gapura. Keberadaan tanaman dan taman yang ada di lingkungan gapura ini yang selanjutnya akan dianalisa posisi dan perletakannya di gapura yang dijadikan contoh kreasi desainnya pada penelitian ini.

Olahan konsep green design yang ditunjukkan pada gapura dalam upaya membentuk identitas lingkungan memiliki hasil arahan dengan meletakkan konfigurasi tanaman yang menarik pada bangunan gapura dan di sekitarnya. Hasil analisa lain adalah hadirnya taman akan membentuk kesan green pada lingkungan di sekitar gapura.
\end{abstract}

Kata kunci: Gapura; Identitas; Lingkungan; Tanaman

\section{ABSTRACT}

The environmental identity becomes very important to be realized and cared for because it will be a guide for everyone in it to know its position and whereabouts to the environment. The existence of this is the ease in finding its position in an environment in terms of distance and direction toward a point of its purpose. Thus, an important concern or factor in the analysis of environmental identity is the view, position and distance of a marker in a particular environment.

One of the important study objects in establishing environmental identity is the entrance gate in the neighborhood. In the study of this gate is still raised the concept of green design due to many efforts in the environment of a city that tends to form a green environment in the environment. The concept of green design in the gate is always related to plants and parks that are around the gate. The existence of plants and parks that exist in this gate area which next will be analyzed position and placement in the gate that used as examples of design creations in this study.

Processed green concept design shown in the gate in an effort to form an environmental identity has the result of landing by putting an interesting plant configuration on the gate and around it. Other analysis results are the presence of the park will form a green impression on the environment around the gate.

Keywords: Gate; Identity; Environment; Plants 


\section{PENDAHULUAN}

Gapura memiliki peranan sebagai penanda seseorang dalam memasuki suatu lingkungan tertentu. Peranan ini didukung oleh keberadaan gapura yang selalu berada di posisi awal atau akhir pada suatu rute perjalanan seseorang ketika berada di suatu lingkungannya. Bila seseorang kesulitan mengenali posisi keberadaannya, maka sering kali akan berusaha menemukan gapura ketika seseorang awalnya memasuki suatu lingkungan sebagai awalan rute perjalannya. Fungsi utama ini sekaligus dapat dimanfaatkan sebagai upaya memperkuat identitas keberadaan gapura dengan berbagai elemen pendukung desainnya. Mengenai pola perjalanan dan rute saat seseorang melintasi suatu obyek ini adalah sejalan dengan pemikiran Farber dan kawan-kawan (2015).

Konsep green design yang diterapkan pada analisa desain gapura adalah sejalan dengan banyaknya upaya masyarakat dalam mewujudkan ruang hijau di kota. Berbagai sudut kota diupayakan untuk diisi dengan tanaman dan taman. Kesadaran dan semangat green design ini yang selanjutnya dapat dimanfaatkan untuk menggali lebih dalam mengenai desain gapura di suatu lingkungan.

\section{A. Permasalahan Desain Gapura dan Konsep Green Design}

Permasalahan utama yang ada di dalam upaya mewujudkan identitas lingkungan melalui gapura ini adalah posisi meletakkan tanaman dan taman di sekitar gapura. Permasalahan tersebut akan dilanjutkaan dengan pemilihan jenis tanaman yang sesuai. Perletakan tanaman sering kali menjadi perhatian minor pada desain gapura dikarenakan desain gapura biasanya bertitik berat pada bentukan gapuranya, sehingga tanaman dan taman di sekitarnya hanya mempunyai peran sebagai pendukung keberadaan bentukan gapura.

Upaya yang dapat dikembangkan dari permasalahan yang ada di atas adalah meletakkan tanaman dengan peran sebagai factor utama pembentuk gapura dan tidak hanya sebagai pendukung dari bentukan gapura yang ada. Permasalahan ini menjadi menarik dikarenakan lingkungan gapura biasanya tidak memiliki luasan yang cukup besar untuk diolah desain taman dan tanaman di dalamnya.

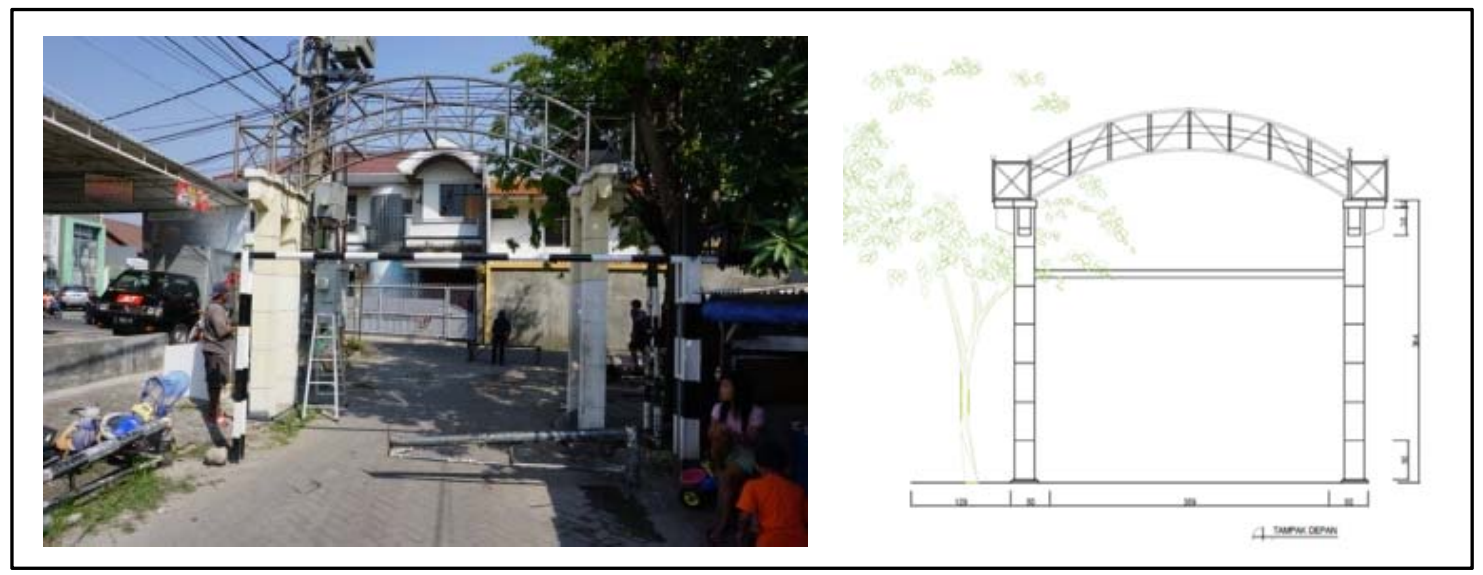

Gambar 1. Bentukan awal gapura yang menitik beratkan pada bentukan gapuranya. Sumber: Data Pribadi (2017)

Kondisi tanaman dan taman sebagai pendukung bentuk gapura yang ada biasanya akan menyebabkan tanaman dan taman akan diolah belakangan dan jarang yang menempelkan 
tanaman pada badan gapura. Kendala ini akan dicoba untuk diatasi dengan meletakkan tanaman pada badan gapuranya. Dengan demikian akan terdapat tanaman yang menempel pada badan gapura.

\section{METODE DALAM MENGANALISA DAN MENGHASILKAN DESAIN GAPURA}

Metode analisa yang sesuai di sini adalah manganalisa bantuk dasar gapura terhadap arah view di sekitarnya. Tahapan selanjutnya adalah meletakkan tanaman yang sesuai untuk memperkuat keberadaan dan bentukan gapura yang ada. Tahapan terakhir adalah mengoptimalkan hasil desain yang diperoleh dengan olahan taman kecil di sekitar gapura. Pola pembentukan gapura yang ada menunjukkan bahwa ada beberapa faktor tambahan yang perlu diperhatikan yakni jarak gapura terhadap obyek lainnya di sekitarnya. Semakin besar jarak gapura terhadap obyek di sekitarnya, maka akan semakin mudah menjadikan gapura sebagai identitas yang kuat. Pemikiran pentingnya mempertimbangkan faktor manusia saat seseorang melintasi suatu obyek seperti saat dengan kebutuhan tertentu adalah sebagaimana juga diutarakan oleh Allen dan kawan-kawan (2014) serta Zhu dan Shi (2016).

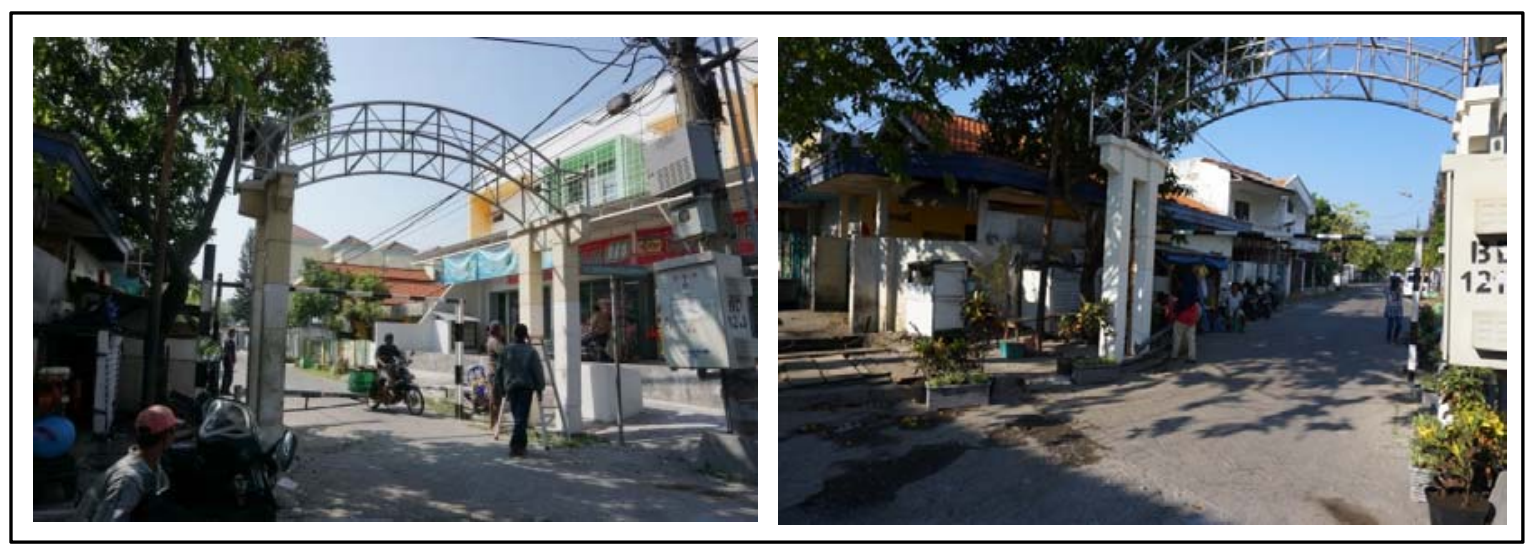

Gambar 2. Pola jalan yang melintasi gapura.

Sumber: Data Pribadi (2017)

Hasil akhir dari analisa bentukan di atas adalah bahwa green design menjadi salah satu alternatif dalam upaya membentuk gapura sebagai identitas yang kuat di lingkungannya. Green design di sini diwujudkan melalui perletakan dan olahan tanaman serta hadirnya taman di sekitar gapura. Green design gapura menjadi salah satu alternatif dalam memperkuat identitas gapura dikarenakan perkuatan karakter olahan tanaman yang dapat sekaligus memperkaya permukaan gapura. 


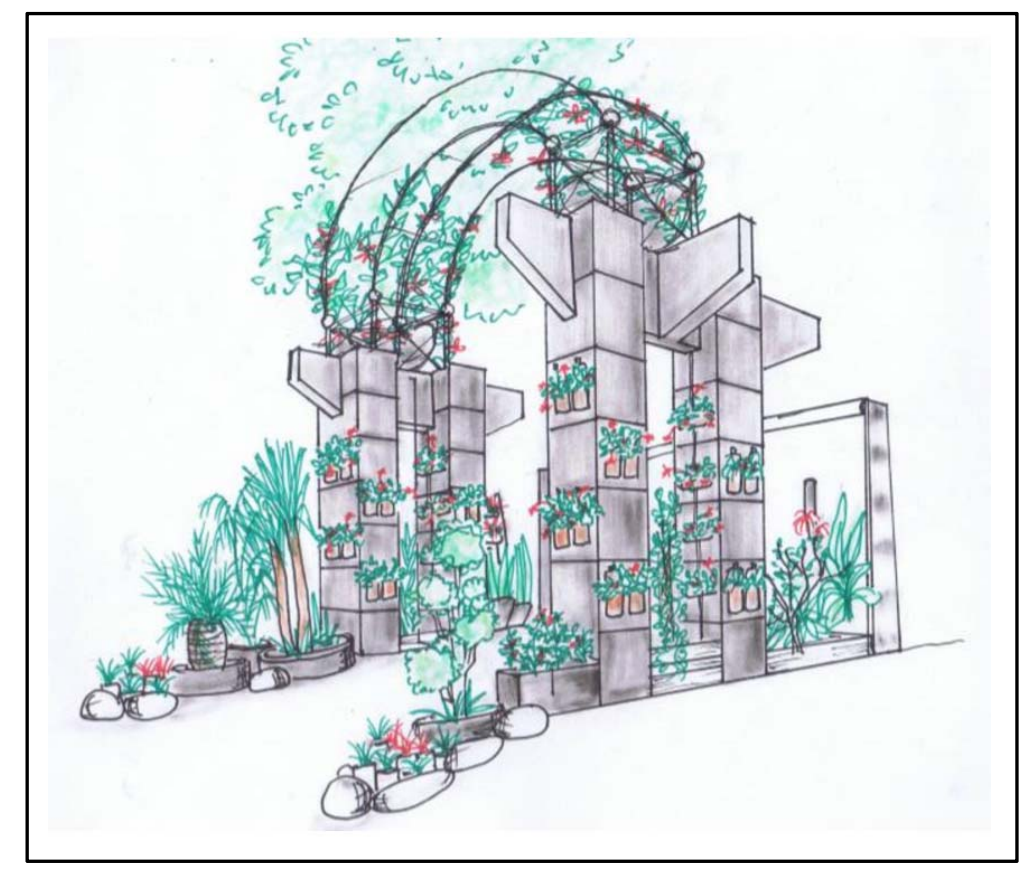

Gambar 3. Gapura dan Olahan Tanaman.

Sumber: Nadya Rizky Fitriana

\section{OPTIMALISASI GREEN DESIGN PADA GAPURA SEBAGAI PEMBENTUK IDENTITAS LINGKUNGAN}

Pengertian green design pada bidang desain landscape dapat dimaknai secara sederhana sebagai pemanfaatan tanaman dalam upaya memperkuat ekologi lingkungannya. Upaya ini dimungkinkan untuk dilaksanakan melalui memasukkan unsur tanaman di lingkungan yang dirancangnya. Tanaman yang dimanfaatkan pada rancangan ini adalah dengan mengkonsepkannya dengan bentukan yang sesuai dengan keinginan perancangannya. Salah satu upaya untuk mencari tanaman yang sesuai adalah dengan ukuran dari bentukan kelompok tanaman tersebut.

Jenis-jenis tanaman yang dapat digunakan adalah seperti tanaman rambat, tanaman hias dan tanaman penutup permukaan tanah. Berbagai fungsi di atas dimaksudkan untuk mempermudah upaya perkuatan bentukan gapura dan identitas bentuk sekitar gapuranya. Kedua upaya ini dapat dimanfaatkan bersamaan untuk memperkaya hasil desainnya.

Upaya dalam memperkuat bentukan gapura dilaksanakan dengan memilih dan meletakkan tanaman di badan gapura. Manfaat lain dari meletakkan tanaman pada gapuranya adalah sebagai upaya memperkaya warna dan tekstur badan gapura yang ada. Hal ini adalah dikarenakan bentukan tanaman memiliki kandungan warna daun dan bunga yang menarik serta memiliki tekstur tertentu dari komposisi susunan daun dan bunganya. Jadi, badan gapura akan sangat menjadi kaya akan warna dan tekstur dari tanaman yang diletakkan pada badan gapuranya.

Upaya dalam memperkuat identitas di sekitar gapura dapat dilaksanakan dengan meletakkan tanaman di sekitar bentuk gapuranya. Manfaat lain dari kegiatan meletakkan tanaman di sekitar gapura adalah menjadikan tanaman sebagai space pengantar (ruang peralihan) dari kondisi jalan di sekitar gapura kepada bentukan gapuranya. 


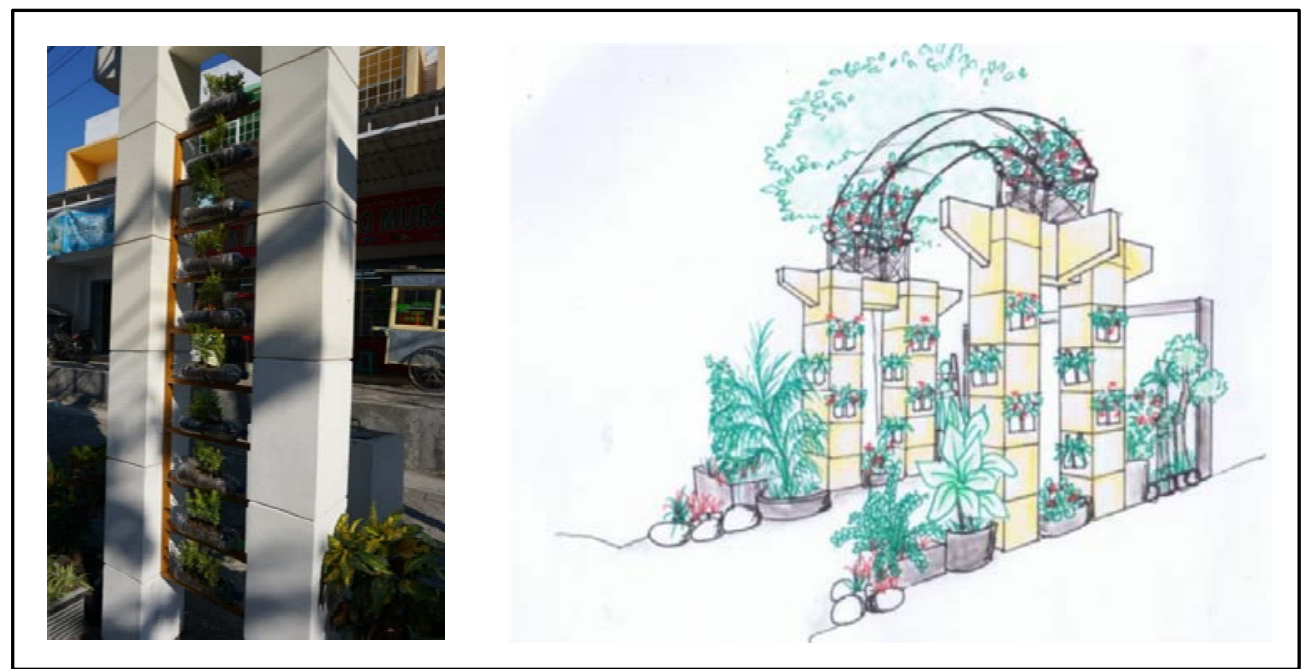

Gambar 4. Tanaman pada badan gapura.

Sumber: Data Pribadi dan Nadya Nadya Rizky Fitriana

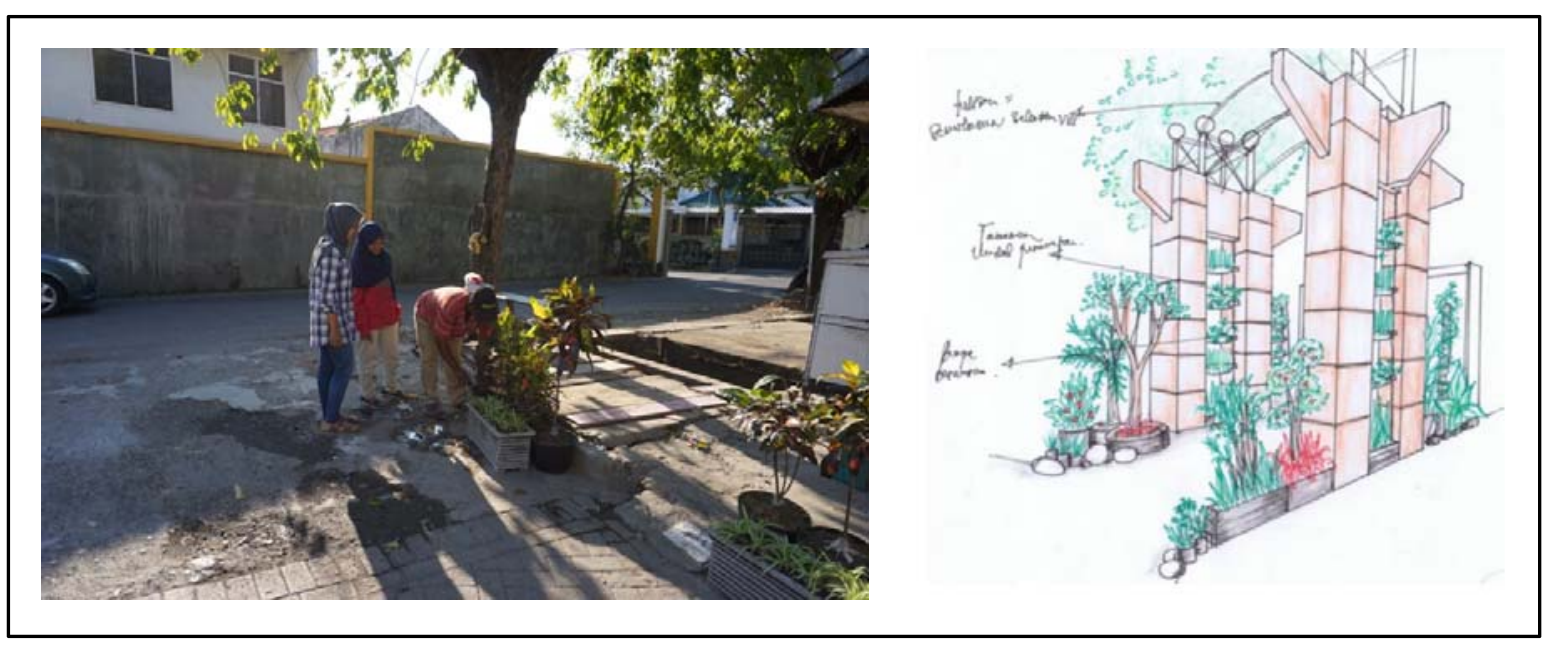

Gambar 5. Tanaman pada sekitar badan gapura.

Sumber: Data Pribadi dan Nadya Nadya Rizky Fitriana

\section{KESIMPULAN PENERAPAN KONSEP GREEN DESIGN PADA LINGKUNGAN GAPURA}

Konsep green design pada lingkungan luasannya yang berukuran kecil seperti gapura ini menjadi tantangan tersendiri bagi desainer untuk mewujudkannya. Green design akhirnya diwujudkan dengan memberikan elemen tanaman dan taman pada badan gapura dan di sektor badan gapuranya. Tantangan yang ada di sini adalah seperti pemilihan jenis tanaman dan pola dalam menyusun perletakannya. Akhirnya, tantangan tersebut dapat dijawab melalui hasil olahan tanaman dan tamannya.

Konsep green design pada gapura juga memberikan manfaat lain sebagai pembentuk identitas pada pintu masuk di wilayah tertentu. Manfaat ini diwujudkan dari perkayaan 
bentukan tekstur dan pengkayaan badan gapura dari tekstur tanaman yang ada. Bentukan yang semula hanya obyek gapura saja kemudian akan diperkaya dengan hadirnya tanaman dan taman di sekitarnya.

Olahan tanaman dan taman pada konsep green design di gapura ini juga harus memperhatikan arah view dan jalan yang ada disekitar gapura. Arah view harus sejalan dengan jarak antara yang dimiliki oleh pengamat terhadap posisi gapuranya. Arah view ini akan menghasilkan bentukan yang berfokus pada bagian badan gapura. Jadi, klimaks puncak view ada pada bagian badan gapura di tengah perjalanan saat seseorang melintasi gapura tersebut.

\section{DAFTAR PUSTAKA}

Jennifer Dacey Allen, Caitin Caspi, May Yang, Bryan Leyva, Anne M. Stoddard, Sara Tanners, Reginald D. Tucker-seeley, Glorian C. Sorensen (2014). Pathways between acculturation and health behaviors among residents of low-income housing: The mediating role of social and contextual factors. Social Science \& Medicine hal. 123, 26 -36 .

Kong-jin Zhu, Qin Shi (2016). Experimental study on choice behavior of pedestrians during building evacuation. Procedia Engineering hal. 135, 207 - 216.

Steven Farber, Morton O’Kelly, Harvey J. Miller, Tijs Neutens (2015). Measuring segegration using patterns of daily travel behavior: A social interaction based model of exposure. Journal of Transport Geography, hal. 49, 26 - 38. 